\title{
Mathematical Reasoning in a Technological Environment
}

\author{
Jill VINCENT \\ Department of Science and Mathematics Education, The University of Melbourne \\ Victoria, 3010 Australia \\ e-mail: jlvinc@unimelb.edu.au
}

Received: March 2003

\begin{abstract}
Dynamic geometry software has been accused of contributing to an empirical approach to school geometry. However, used appropriately it can provide students with a visually rich environment for conjecturing and proving. Year 8 students who were novices with regard to geometric proof were able to exploit the features of Cabri Geometry II to assist them in formulating and proving in the context of Cabri simulations of mechanical linkages.
\end{abstract}

Key words: dynamic geometry software, geometric proof, deductive reasoning.

\section{Introduction}

Most mathematicians would agree that it is proof which sets mathematics apart from the empirical sciences, and forms the foundation of our mathematical knowledge. Yet research indicates that students often fail to understand the purpose of mathematical proof, and readily base their conviction on empirical evidence or the authority of a textbook or teacher. A large-scale survey of above average Year 10 students in the UK (Healy and Hoyles, 1999), for example, has shown that many students, even those who have been taught proof, have little idea of the significance of mathematical proof, are unable to recognise a valid proof, and are unable to construct a proof in either familiar or unfamiliar contexts. Mathematics curricula in many countries are now emphasising the need for students to justify and explain their reasoning. A further important issue is the introduction into schools of a class of software known as dynamic geometry, such as Cabri Geometry II $^{\mathrm{TM}}$ and The Geometer's Sketchpad ${ }^{\circledR}$. Screen drawings in this software can be purely visual or they can be constructed using in-built tools based on Euclidean geometry, such as parallel or perpendicular lines, angle bisectors or perpendicular bisectors; segments or angles can be constructed precisely; accurate measurements can be made; and the loci of points traced. The 'drag' facility distinguishes dynamic geometry software from other computer drawing software, since only those features based on the use of appropriate geometric tools, such as parallel or perpendicular lines, will remain invariant when a screen drawing is dragged. These dynamic geometry environments have created widespread interest as constructivist learning tools, and have the potential to transform the teaching and learning of geometry. 
Despite this potential, though, concern has been expressed that dynamic geometry software is contributing to an empirical approach to geometry. Noss and Hoyles (1996) note that in the UK, for example, geometry is being reduced to pattern-spotting in data generated by dragging and measurement of screen drawings, with little or no emphasis on theoretical geometry: "school mathematics is poised to incorporate powerful dynamic geometry tools in order merely to spot patterns and generate cases" (p. 235). Hölzl (2001) asserts, however, that the problem lies with the way dynamic geometry software is used, rather than with the software itself:

The often mentioned fear that the computer hinders the development of an already problematic need for proof is too sweeping. It is the context in which the computer is a part of the teaching and learning arrangement that strongly influences the ways in which the need for proof does - or does not - arise (pp. 68-69).

De Villiers (1998) has criticised the emphasis on the verification aspect of proof in school mathematics, asserting that in a dynamic geometry environment the focus should move to proof as explanation rather than verification. While some students may have a cognitive need for proof as conviction, many see little point in proving something which they already 'know' to be true. Hofstadter (1997, p. 10) argues that the certainty given by dragging a dynamic geometry construction is more convincing for him than a proof: "it's not a proof, of course, but in some sense, I would argue, this kind of direct contact with the phenomenon is even more convincing than a proof, because you really see it all happening right before your eyes". The question, then, is how to exploit the rich visual environment of dynamic geometry software to engage students in deductive reasoning and proof. Scher $(1999$, p. 24) suggests that through an interplay between experimentation and deductive reasoning, "dynamic geometry can provide not only data to feed a conjecture, but tools to jump-start ideas and feed a proof".

\section{Mechanical Linkages as a Pathway to Deductive Reasoning}

My quest for a motivating, visually rich context in which to introduce Year 8 students to geometric proof led me to mechanical linkages, or systems of hinged rods (see Cundy and Rollett, 1981; Bolt, 1991). Found in many common household items, as well as in 'mathematical machines' from the past, mechanical linkages are often based on simple geometry such as similar figures, isosceles triangles, parallelograms or kites. With the emphasis on the underlying geometry, dynamic geometry software models of linkages provide an interface between the concrete and the theoretical, and a visually rich environment for students to explore, conjecture and construct geometric proofs. In this context of mechanical linkages, proof has the functions of verification of the truth of conjectures, promoting understanding of geometric relationships, and explanation, that is, giving insight into why a particular linkage works the way it does. 


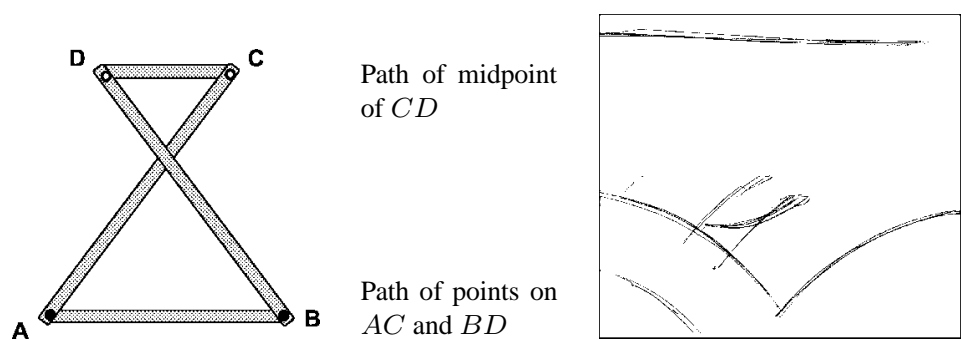

Fig. 1. Pencil-and-paper: Tracing the paths of points on Tchebycheff's linkage.

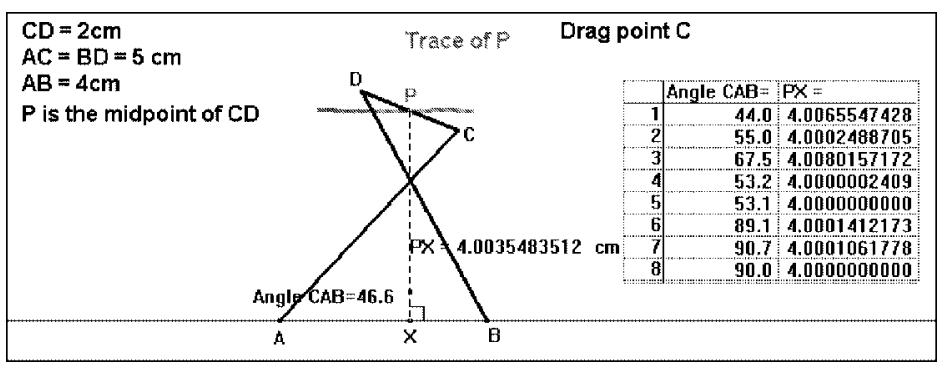

Fig. 2. Cabri model of Tchebycheff's linkage.

\section{Developing a Cognitive Need for Proof}

In a research experiment with Year 8 students, Tchebycheff's linkage (Cundy and Rollett, 1981) for approximate linear motion (see Fig. 1) was introduced as a means of developing a cognitive need for geometric proof. The linkage consists of three rigid bars, $A C, B D$ and $C D$, with lengths five, five, and two units respectively. Points $A$ and $B$ are fixed, with the distance $A B$ equal to four units. When $C D$ rotates, the midpoint of $C D$ moves along an almost linear path. The students first constructed the linkage from plastic strips, and conjectured that the midpoint of $C D$ moved in a straight line.

Fig. 2 shows a Cabri Geometry II (referred to from now on as Cabri) model of Tchebycheff's linkage, with the tabulated measurement data and the trace of point $P$ (the midpoint of $C D$ ) demonstrating the closeness of the path of $P$ to linear motion. When the students dragged the Cabri linkage, their realisation that the path was not in fact linear, and their astonishment at seeing how little the path actually deviated from a straight line, was sufficient to convince them that visual and empirical evidence could not be trusted.

\section{Computer Simulations of Other Mechanical Linkages}

\section{Linkages which Produce True Linear Motion}

During the nineteenth century several mathematicians became involved in designing linkages for converting circular motion to linear motion. Sylvester's linkage (Fig. 3), for 


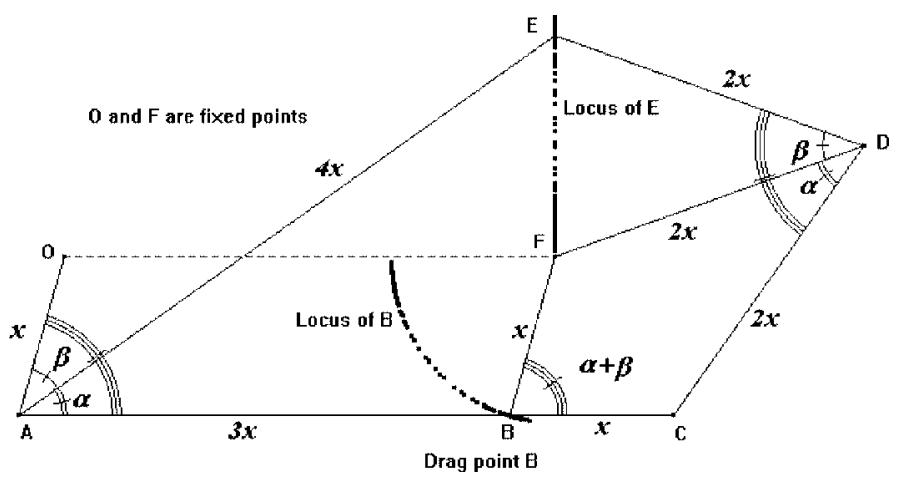

Fig. 3. Cabri model of Sylvester's straight-line linkage.

example, is based on two similar kites, $A E D C$ and $D C B F$, with $O$ and $F$ fixed so that $O A B F$ is a parallelogram. As point $B$ is dragged, the locus of $E$ appears to be a straight line through $F$, while measurement of angles suggests that $\angle O F E$ is a rightangle. Using the geometry of the similar kites and the parallelogram, $O A B F$, it can be proved that $\angle O F E$ is indeed a right-angle.

\section{Pantographs}

Pantographs - mechanical devices used for copying or enlarging drawings - are readily modelled using dynamic geometry software. Sylvester's pantograph (Fig. 4) consists of a parallelogram $O A B C$ and two links, $A P$ and $C P^{\prime}$, where $A P=A B=O C, C P^{\prime}=$ $C B=O A$ and $\angle B A P=\angle B C P^{\prime}=\alpha$, a fixed angle. Tracing the paths of $P$ and $P^{\prime}$ as $P$ is dragged, demonstrates to students that $P^{\prime}$ traces out a rotated image of the path of $P$. Feedback from dragging the dynamic geometry model and measurement of $O P, O P^{\prime}$ and $\angle P O P^{\prime}$ should lead students to the conjectures that $O P=O P^{\prime}$ and $\angle P O P^{\prime}=\alpha$. Proof of these conjectures, based on congruent triangles $O A P$ and $O B P^{\prime}$, then confirms why the movement of $P^{\prime}$ is an image of the movement of $P$, rotated through an angle equal to $\alpha$.

The pantograph shown in Fig. 5, in which $A B D C$ is a parallelogram, points $O, C$ and $E$ are collinear, and $O$ is fixed, can be used for enlarging or reducing. By tracing the locus of points $C$ and $E$ students can compare the sizes of the loci and construct a proof based on the conjecture that $\triangle O A C, \triangle O B E$, and $\triangle C D E$ are similar.

\section{Pascal's Angle Trisector}

In Pascal's angle trisector (see Fig. 6), $O A=A P=P B$ so that triangles $O A P$ and $A P B$ are isosceles triangles. Rods $O C$ and $O D$ are hinged at $O$ and $\operatorname{rod} A P$ is hinged at $A$. As the rod $O D$ is rotated to change the size of $\angle B P C, B$ slides along $O D$ and $P$ slides along $O C$. The proof that $\angle B O P$ is one third of $\angle B P C$ is based on exterior angles of triangles. 


\section{Year 8 Students' Conjecturing and Proving}

This section focuses on the role of feedback from Cabri linkage models during argumentation, conjecturing, and proving by two pairs of Year 8 students - Anna and Kate, and Lucy and Rose - who were novices with regard to geometric proof. The students were able to exploit the features of Cabri to assist them in formulating and proving in the context of Cabri simulations of mechanical linkages. In the transcriptions included in this section, TR refers to the teacher-researcher.

\section{Anna and Kate: Pascal's Angle Trisector}

Pascal's angle trisector was Anna and Kate's first linkage task, and their first attempt at conjecturing and proving. They commenced their investigation of the linkage with a metal strip model (see Fig. 7a) which was introduced to them as 'Pascal's mathematical machine' so they did not know the purpose of the device. Their knowledge of isosceles triangles and exterior angles of triangles soon led them to the angle relationships shown in Fig. $7 b$.

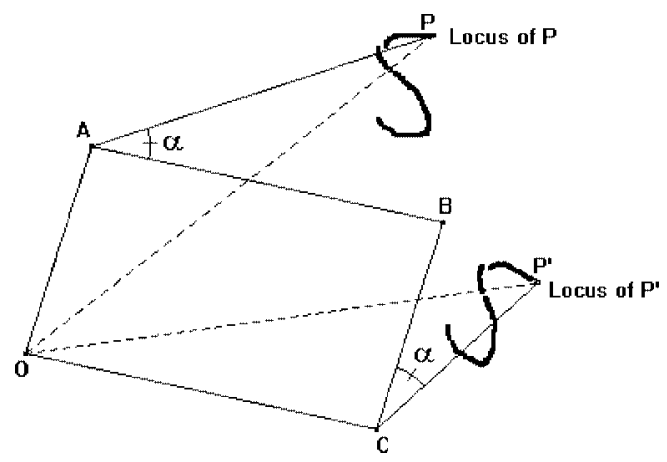

Fig. 4. Sylvester's pantograph.

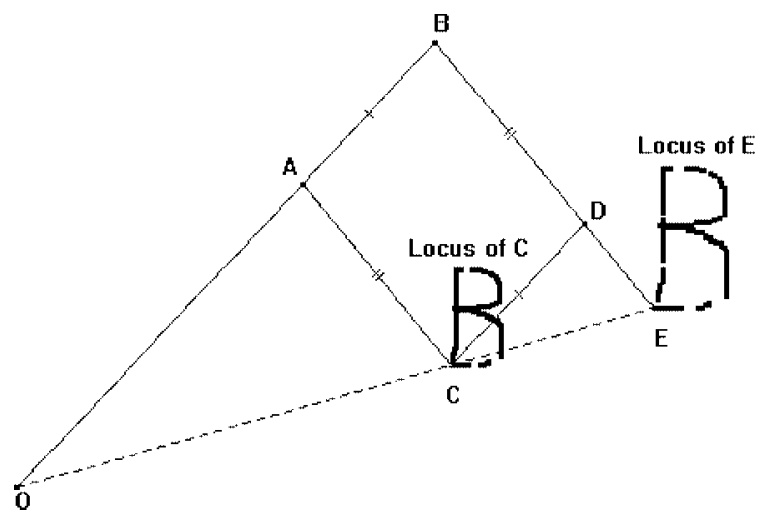

Fig. 5. Cabri model of an enlarging or reducing pantograph. 


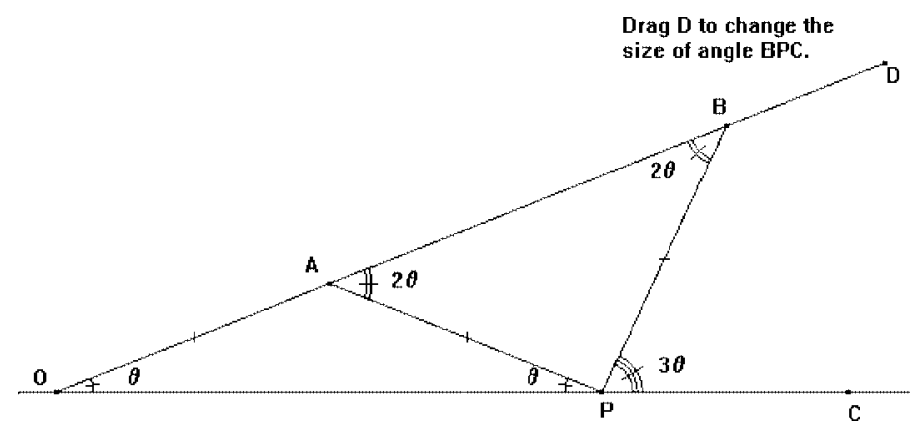

Fig. 6. Cabri model of Pascal's angle trisector.

However, Anna and Kate were unable to make any further progress in their reasoning until they were given the Cabri model (see Figs. 8 and 9). They measured angles in the Cabri figure (Fig. 9a) then tried to find relationships between the angles (Fig. 9b). Kate observed that 55.8 plus 27.9 was equal to 83.7, and therefore that $\angle B D C+\angle B A C=$ $\angle D C X$. Initially they had observed only the two triangles, $A B C$ and $B C D$. Dragging of the Cabri figure allowed Anna and Kate to notice $\triangle C A D$, and they then recognised that $\angle D C X$ was in fact an exterior angle of $\triangle C A D$, and that $\angle D C X$ was equal to three times $\angle B A C$.

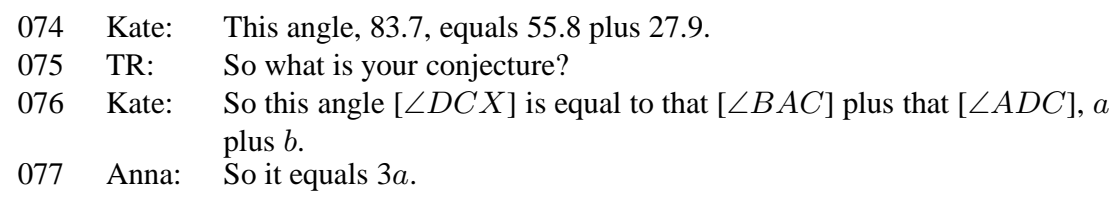

Anna and Kate's written proof is shown in Fig. 10.

Lucy and Rose: Sylvester's Pantograph

Sylvester's pantograph was the fourth conjecturing-proving task completed by Lucy and Rose. The students commenced with a plastic model of a rhombus version of Sylvester's

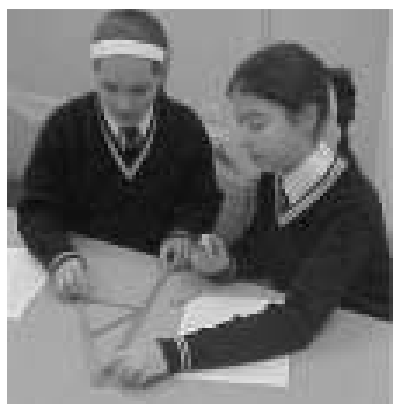

(a)

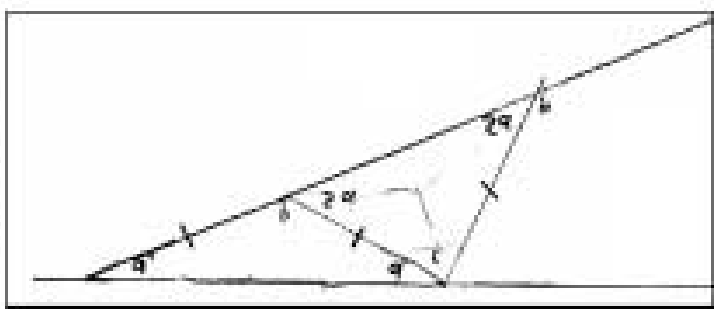

(b)

Fig. 7. Anna and Kate: Investigating Pascal's angle trisector. 


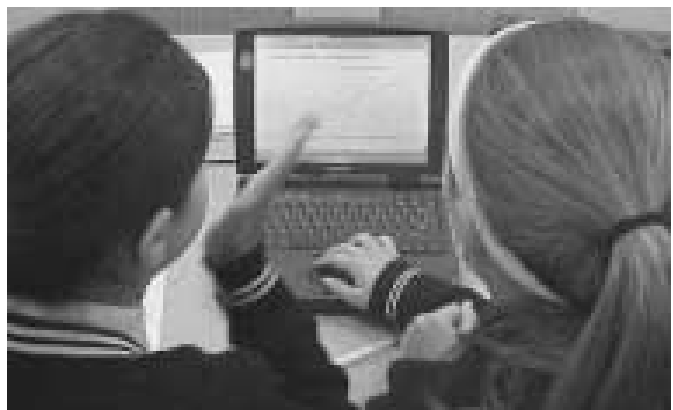

Fig. 8. Anna and Kate investigating the Cabri model of Pascal's angle trisector.

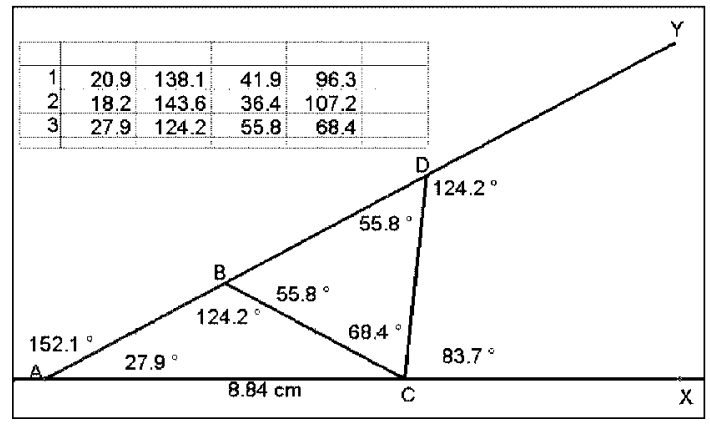

(a)

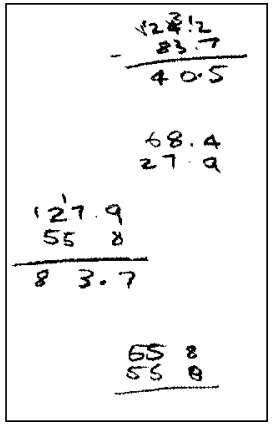

(b)

Fig. 9. Using empirical Cabri data to formulate a conjecture.

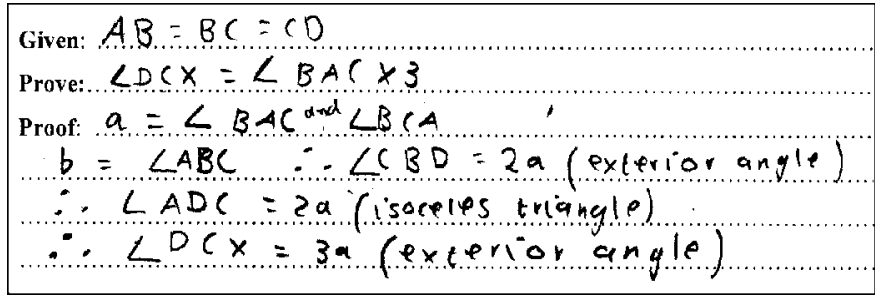

Fig. 10. Anna and Kate's written proof for Pascal's angle trisector.

pantograph, conjecturing that the image was congruent to the shape they had drawn on the paper. Rose also tentatively suggested that the image was rotated by the fixed angle of the pantograph: "Maybe that angle ... I'm not sure ... maybe not ...". They were then given a Cabri model of the pantograph where the distances $O A, A B, B C, O C, A P$, and $C P^{\prime}$ were all equal, and $\angle P A B=\angle P^{\prime} C B=30^{\circ}$. Lucy used the Cabri Triangle tool to draw a triangle with one of its vertices coinciding with point $P$, then selected Trace for point $P^{\prime}$. She dragged $P$ around her triangle so that a trace of the path of $P^{\prime}$ was drawn (see Fig. 11a).

Lucy then placed points at the vertices of the trace formed by $P^{\prime}$, and removed the 
trace to expose the three points, which she then joined with segments (Fig. 11b). Lucy and Rose observed that the two triangles were "about the same", but rotated.

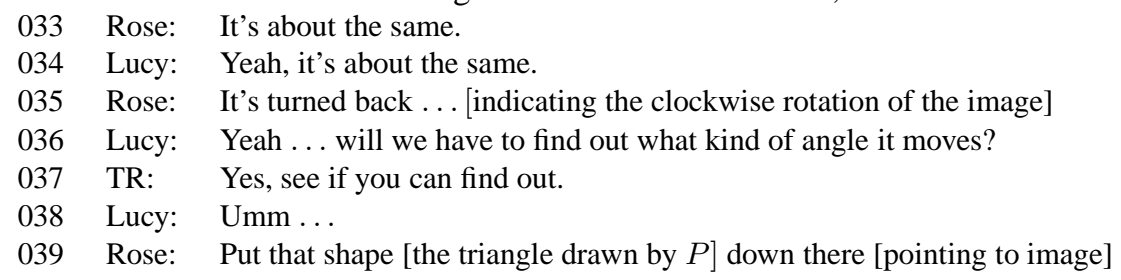

Lucy measured $\angle P A B$ and $\angle P^{\prime} C B$, noting that they were always 30 degrees. Rose then suggested that they should measure the angle between corresponding sides of the original triangle and the one they had drawn over the trace (see Fig. 12). Lucy had anticipated that the angle would be 30 degrees, but probably recognised the inaccuracy associated with constructing the triangle over the trace and moving the original triangle to coincide with this second triangle.

042 Lucy: So it's 30 degrees the whole time [ $\angle P A B$ and $\left.\angle P^{\prime} C B\right]$.

043 Rose: So we want to measure ...

044 Lucy: This angle? Twenty-nine point one ... it's point nine off.

Based on the accurate feedback from the Cabri model, Lucy and Rose were now able

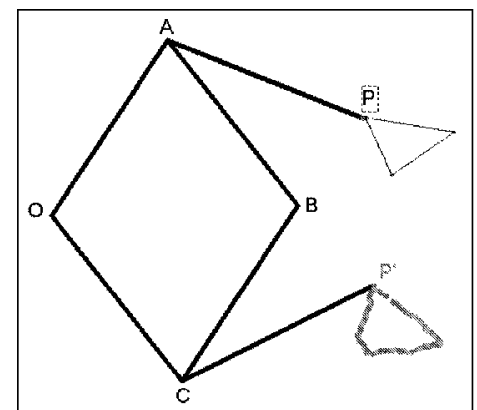

(a)

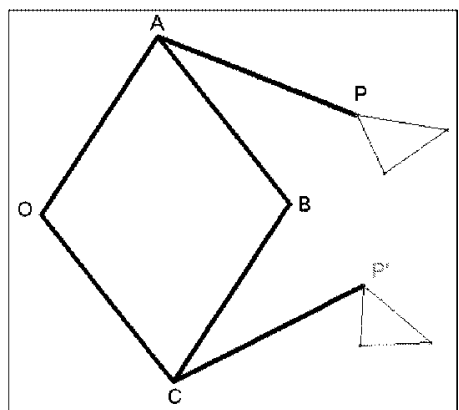

(b)

Fig. 11. Using the Cabri model to investigate Sylvester's pantograph.

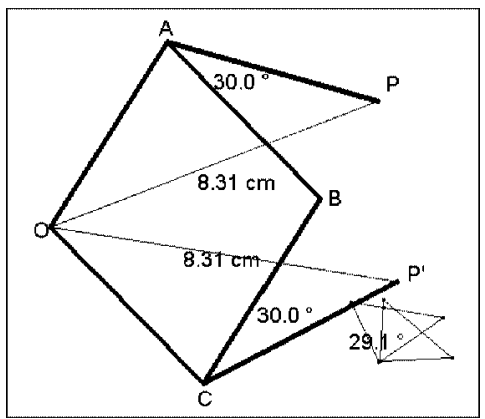

Fig. 12. Measuring the angle of rotation of the image at $P^{\prime}$. 
to formulate conjectures about the operation of the pantograph (see Fig. 13):

045 TR: So what is your conjecture then?

046 Lucy: That the angle which the copy of the shape rotates is that angle of the pantograph.

The two students were still uncertain, however, why the image was rotated:

066 TR: What determines where the image is formed?

067 Rose: The smaller this angle $[A B C]$ the further out these go $\left[P\right.$ and $\left.P^{\prime}\right]$ and the further apart these $\left[P\right.$ and $\left.P^{\prime}\right]$ get ...

068 Lucy: Oh ... so they do get further apart ...

069 Rose: If you just rotate it ...

070 Lucy: When you move it round a shape they stay the same distance apart.

071 Rose: Yeah ...

072 TR: Look at where the linkage is attached to the paper and watch that in relation to the object and the image.

073 Rose: Perhaps this angle is always the same ...

074 TR: Which angle do you mean?

075 Rose: This one ... from that point $[P]$ to that point $[O]$ to there $\left[P^{\prime}\right]$.

Rose drew $O P$ and $O P^{\prime}$ on the Cabri figure and measured $\angle P O P^{\prime}$ (see Fig. 14), which led the students to recognise that $\angle P O P^{\prime}$ was the angle of rotation and that it was equal to the fixed angles of the pantograph $\left(\angle P A B\right.$ and $\left.\angle P^{\prime} C B\right)$ :

076 Rose: Measure the angle.

077 Lucy: OK ... measure angle. Yep, $30 \ldots$

Lucy and Rose now understood the angle relationships of the pantograph (see Fig. 15) and were able to see why the angle of rotation (labelled $d$ on their diagram) was equal to the fixed angles of the pantograph (labelled $a$ ) on the diagram).

When Lucy and Rose began to construct their written proof (see Fig. 16), they had a clear understanding of the logical order of statements in their proof, as indicated by Rose's comment “We shouldn't do that yet” (turn 087).

087 Rose: Let's do the sides first. $O A$ equals $A P$ equals $O C$ equals $C P^{\prime} \ldots$ then angle $O C P$ equals ...OPB because they both have 30 degrees ... they share 30 degrees ... we shouldn't do that yet. Angle $O A \ldots$ angle $O A B$ equals ...

088 Lucy: Angle $O C B$

\section{Conjecture 1:}

Make a conjecture about the size of the image compared with the size of the original shape.

The image i..... shape are congruent

Conjecture 2:

Make a conjecture about the rotation of the image compared with the position of the original shape The image ratates $\angle B A P$ o $A \angle B C P$

Fig. 13. Lucy and Rose's conjectures for Sylvester's pantograph. 


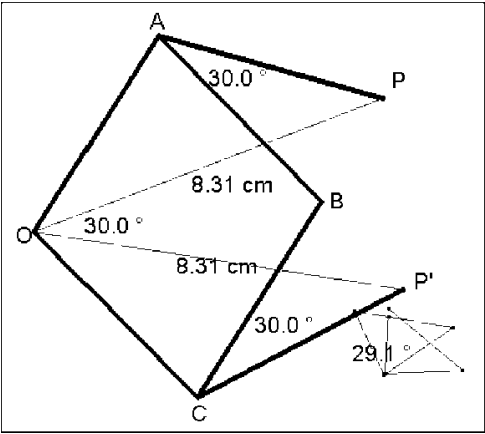

Fig. 14. Measuring $\angle P O P^{\prime}$
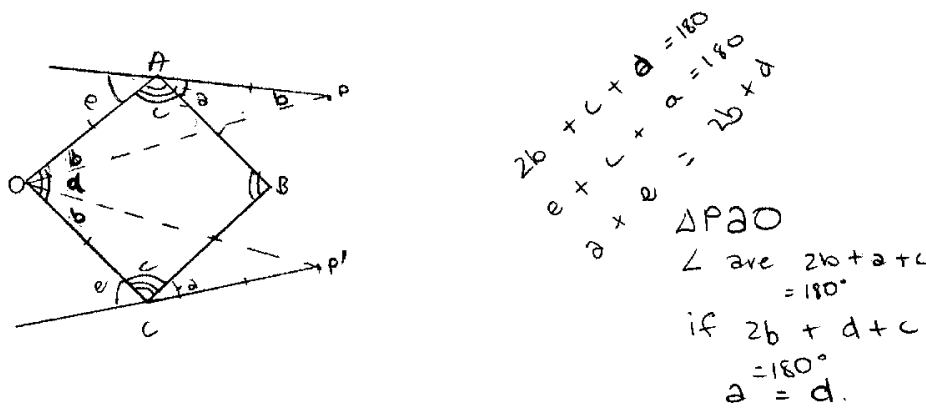

Fig. 15. Identifying angle relationships in Sylvester's pantograph.

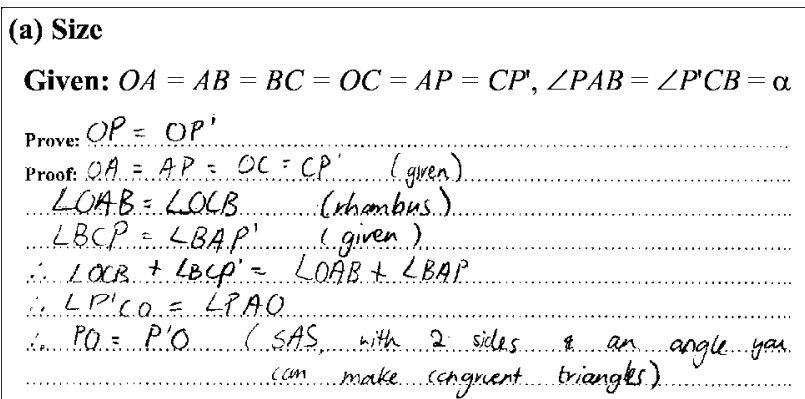

\section{(b) Rotation}

Given: $O A=A B=B C=O C=A P=C P^{\natural}, \angle P A B=\angle P^{\prime} C B=\alpha$ Prave $\angle P O P^{\prime}=\angle P A B \quad \angle P^{\prime} C B$

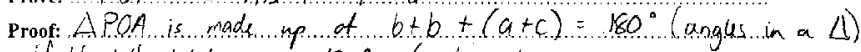
if $\angle b+b b+\angle d+c=180^{\circ}$ (adjasent angles in a rhemeas $\therefore \angle a=L d \quad$ are supplemextary.

Fig. 16. Lucy and Rose: Written proof for Sylvester's pantograph. 
089 Rose: And angle $B C P^{\prime}$ equals $B A P$ because given $\ldots O A B$ plus $B C P^{\prime} \ldots$

090 Lucy: Those two added together, that whole angle ... that means ...

091 Rose: Once we've proved that angle, then the whole thing's easy 'cause side angle side ... see, if you have two sides and how big it's going to be in between ... when you join them up the triangles will be the same...

092 Lucy: Oh, yep. So ... angle $P^{\prime} C O$ will be equal to ...

093 Rose: Therefore . . $P^{\prime} C O$ equals $P A O$ because ... say side angle side so it makes congruent triangles. So $O P$ equals $O P^{\prime}$.

094 Lucy: Right, now prove that $P O P^{\prime}$ equals angle $P^{\prime} C B$ and $P A B$. In triangle POA...

\section{Conclusion}

The students involved in the sequence of conjecturing-proving tasks displayed high levels of motivation, no doubt due in part to the tactile and novel experience of working with physical models of the linkages. It was, however, the accuracy of the feedback from the Cabri models which allowed the students to formulate their conjectures, and gave them the confidence and motivation to seek explanations for these conjectures. The unique features of dynamic geometry software - constructions based on Euclidean geometry, accurate measurements, tabulation of data, and the tracing of loci and the drag facility - rather than eliminating the need for proof, created a visually rich and motivating environment for these Year 8 students to explore, conjecture and construct geometric proofs.

\section{References}

Bolt, B. (1991). Mathematics Meets Technology. Cambridge University Press, Cambridge.

Cundy, H.M., and A.P. Rollett (1981). Mathematical Models. Tarquin Publications, Norfolk, England.

De Villiers, M. (1998). An alternative approach to proof in dynamic geometry. In R. Lehrer and D. Chazan (Eds.), Designing Learning Environments for Developing Understanding of Geometry and Space. Lawrence Erlbaum Associates, Hillsdale, NJ, pp. 369-393.

Healy, L., and C. Hoyles (1999). Technical Report on the Nationwide Survey: Justifying and Proving in School Mathematics. Institute of Education, University of London, London.

Hofstadter, D. (1997). Discovery and dissection of a geometric gem. In J. King and D. Schattschneider (Eds.), Geometry Turned on: Dynamic Software in Learning, Teaching, and Research, MAA Notes 41. The Mathematical Association of America, Washington, DC, pp. 3-14.

Hölzl, R. (2001). Using dynamic geometry software to add contrast to geometric situations - A case study. International Journal of Computers for Mathematical Learning, 6, 63-86.

Noss, R., and C. Hoyles (1996). Windows on Mathematical Meanings: Learning Cultures and Computers. Mathematics Education Library, 17, Kluwer Academic Press Dordrecht, The Netherlands.

Scher, D. (1999). Problem solving and proof in the age of dynamic geometry. Micromath, 15 (1), 24-30. 
J. Vincent studied mathematics and chemistry at the University of Melbourne, Australia, and has had 22 years experience teaching mathematics and science. Since 1991 she has been teaching mathematics at Melbourne Girls Grammar School, and is also working as a part-time research fellow in the Education Faculty at the University of Melbourne. She has just completed a $\mathrm{PhD}$ in mathematics education, researching the use of dynamic geometry software for introducing Year 8 students to geometric proof. She has written several books for secondary school mathematics, including Computer Enriched Mathematics for Years 7 and 8, and Exploring 2-dimensional Space with Cabri Geometry II, which have been published by the Mathematical Association of Victoria. She has also presented workshops for teachers on the use of Cabri Geometry and MicroWorlds Pro.

\section{Matematinis argumentavimas technologinėje aplinkoje}

\section{Jill VINCENT}

Nors mūsų matematinis išmanymas ir remiasi irodymu, tačiau tyrimai rodo, jog moksleiviai dažnai nesugeba suvokti paties matematinio irodymo tikslo bei savo isitikinimus visiškai nesusimąstydami grindžia empiriniu akivaizdumu arba vadovèlio ar mokytojo autoritetu. Vis dèlto, daugelio šalių matematikos mokymo programose šiuo metu yra pabréžiama moksleiviu gebèjimo pagrịsti ir paaiškinti vienoki ar kitokį savo argumentavimą svarba. Pastaraisiais dešimtmečiais mokyklose imta supažindinti su dinaminès geometrijos programine iranga. Nepaisant visu šios irangos galimybių pertvarkyti geometrijos mokymąsi, dažnai išreiškiamas nepasitenkinimas, kad ir ji prisideda prie tokio, empirinio požiūrio ic geometriją, radimosi mokykloje. Dèl to kyla klausimas, kaip reiktų naudoti dinaminès geometrijos programinès ịangos suteikiamą vizualią aplinką, kad mokiniai būtų skatinami dedukciškai mąstyti.

Daugelyje namų apyvokos reikmenų, o taip pat ir praeityje paplitusiose "matematinèse mašinose", aptinkamu mechaniniu jungčiu veikimas dažnai pagrisstas tradicine geometrija, t. y. panašiosiomis figūromis, lygiašoniais trikampiais, lygiagretainiais ar rombais. Neišleidžiant iš akiu tradicinès geometrijos svarbos, dinaminés geometrijos programinès irangos jungčiu modeliai suteikia tinkamą pagrindą aštuntos klasès moksleiviams aiškintis, numanyti bei sudarinèti geometrinius irodymus. Kompiuteriniai jungčiu modeliai nutiesia tam tikrą pažintini tiltą tarp konkrečiu fiziniu jungčiu ir asociatyviu teoriniu geometrinių figūrų. Šių modeliu dinaminè prigimtis lavina vaizduotę ir skatina argumentuoti. Aštuntos klasès moksleiviai, susipažindami su geometriniais irodymais, ugdo savyje aukštesnio lygio matematinio ịrodymo isisąmoninimo, dedukcinio argumentavimo bei irodymo organizavimo igūdžius. Šiame straipsnyje taip pat diskutuojama apie Čebyševo modeliu naudingumą siekiant parodyti geometrinio įrodymo vertę bei pateikiami pavyzdžiai iš moksleivių diskusiju apie Paskalio ir Silvestro figūras. 